\title{
UJI APLIKASI AGENS HAYATI TRIBAC MENGENDALIKAN PATHOGEN HAWAR DAUN (Helminthosporium sp.) TANAMAN JAGUNG (Zea mays L.)
}

\author{
Application Test of Tribac Body Agents Controlling the Pathogen of Leaves (Helminthosporium sp.) \\ Corn Plant (Zea mays L.) \\ Warlinson Girsang ${ }^{1}$, Jonner Purba ${ }^{2}$, dan Suryadi Daulay ${ }^{3}$ \\ 1.2,3 Program Studi Agroteknologi Fakultas Pertanian Universitas Simalungun Pematangsiantar, Sumatera Utara, Indonesia \\ E-mail : warlinsongirsang@gmail.com
}

\begin{abstract}
ABSTRAK
Salah satu jenis penyakit yang sering menyerang tanaman jagung adalah penyakit hawar daun yang disebabkan patogen jamur Helmithosporium sp. Untuk mengendalikan penyakit, petani cenderung mengandalkan pestisida sintetis yang bisa menyeb abkan resistensi hama dan penyakit, menimbulkan pencemaran lingkungan, bahkan merugikan kesehatan manusia. Untuk mencegah dampak negatif pestisida sintesis perlu alternatif lain, misalnya dengan memanfaatkan agen hayati. Dewasa ini telah berhasil dikembangkan produk agen hayati yang diharapkan dapat menggantikan ketergantungan penggunaan pestisida sintesis. Pelaksanaan penelitian menggunakan rancangan acak lengkap, dilakukan di rumah kasa. Faktor yang diteliti ialah pemanfaatan agen hayati Tribac untuk mengendalikan penyakit hawar daun tanaman jagung, dengan menguji 4 tingkat konsentrasi berturut-turut $0,1 \%, 0,2 \%, 0,3 \%$ dan $0,4 \%$ dan 1 perlakuan pembanding tanpa pemberian agens hayati Tribac. Intensitas serangan hawar daun tanaman jagung dihitung menggunakan rumus $: I=\left\{\sum(\mathrm{ni} \times \mathrm{vi}) /(\mathrm{Z} \times \mathrm{N})\right\} \times 100 \%$. Hasil penelitian menyimpulkan, agen hayati Tribac efektif mengendalikan penyakit hawar daun tanaman jagung yang disebabkan pathogen Helminthosporium sp. Tingkat konsentrasi aplikasi agen hayati Tribac 0,4\% menghasilkan intensitas serangan yang terendah.
\end{abstract}

Kata Kunci : Helminthosporium, tribac, intensitas serangan, penyakit hawar daun, jagung

\section{ABSTRACT}

One of the diseases that often attacks the corn plants is a leaf blight disease which is caused by fungal pathogens Helmithosporium sp. To control the disease, farmers tend to rely on synthetic pesticides that can cause pest and disease resistance which are causing the environmental pollution, even detrimental to human health. To prevent the negative effects of pesticide synthesis, another alternative is needed, for example by utilizing the biological agents. Today the biological agent products have been successfully developed which are expected to be able to replace the dependence of using synthetic pesticide. The research implementation uses the complete randomized design which is conducted in screen house. The factors which are examined are the utilization of Tribac biological agents to control the leaf blight disease of corn, by testing 4 consecutive concentration levels $0,1 \%, 0,2 \%, 0,3 \%$ and $0,4 \%$ and 1 comparative treatment without the provision of the Tribac biological agents. The corn leaf blight attacking intensity is calculated by using the formula: $I=\left\{\sum\right.$ (ni $x$ vi) $\left./(Z \times N)\right\} \times 100 \%$. The research result concluded that the Tribac biological agents are effective to control the leaf blight corn plants which arecaused by the pathogenic Helminthosporium sp. The concentration level of the application of Tribac biological agents $0.4 \%$ resulted a decrease of the lowest attacking intensity.

Key words: Helminthosporium, tribac, attacking intensity, leaf blight disease, corn

Diterima : 25 Juli 2020. Disetujui: 20 Agustus 2020 


\section{PENDAHULUAN}

Upaya peningkatan produksi tanaman pangan dipengaruhi adanya faktor pembatas yang bersifat abiotik dan biotik. Faktor pembatas abiotik meliputi terjadinya kemarau yang menyebabkan kekeringan, kekurangan unsur hara dan faktor iklim yang tidak menentu. Sedangkan kendala biotik berupa munculnya serangan organisme pengganggu tanaman, yang berpotensi menimbulkan kerugian. Budidaya tanaman jagung seperti halnya tanaman lain, tidak terlepas dari permasalahan organisma pengganggu tanaman. Tanaman jagung memiliki banyak jenis penyakit terutama disebabkan patogen jamur maupun bakteri. Salah satu jenis penyakit yang sering menyerang tanaman jagung adalah penyakit hawar daun yang disebabkan patogen jamur Helmithosporium sp. (Adisarwanto dan Widyastuti, 2000).

Khususnya di Sumatera Utara, penyakit ini merupakan salah satu penyakit yang menjadi masalah yang sering dihadapi. Penyakit hawar daun Helminthosporium sp. mulai berkembang di Sumatera Utara sejak awal musim tanam 1999/2000, terutama di kabupaten Karo dan kabupaten Simalungun. Selanjutnya penyakit ini menyebar ke kabupaten lain seperti Deli Serdang, Langkat, Dairi, Asahan, Toba Samosir, Tapanuli Utara dan Tapanuli Selatan (Roliyah, 2000).

Kecenderungan petani di Sumatera Utara, untuk mengendalikan penyakit yang disebabkan pathogen jamur dan bakteri masih mengandalkan pestisida sintetik. Hal ini menimbulkan berbagai aspek permasalahan ekonomi maupun aspek lingkungan. Dengan mengandalkan pestisida sintetik, biaya usaha tani yang ditanggung petani semakin meningkat. Sebab dewasa ini harga pestisida sintetik relatif mahal.

Penggunaan pestisida sintetik secara tidak bijaksana, juga memiliki dampak negatif. Pestisida bisa menimbulkan resistensi hama dan penyakit, menyebabkan pencemaran lingkungan (Girsang, 2009), bahkan merugikan kesehatan manusia sebagai konsumen (Saenong, 2007).

Untuk mencegah dampak negatif akibat penggunaan pestisida sintesis, perlu dipikirkan penggunaan alternatif lain, misalnya dengan memanfaatkan agens hayati yang tergolong sebagai pestisida biologi. Pestisida biologi relatif tidak memiliki dampak negatif, seperti halnya pestisida sintesis. Agens hayati adalah setiap organisme yang meliputi spesies, sub spesies atau varietas dari semua jenis serangga, nematoda, protozoa, cendawan, bakteri, virus, mikroplasma serta organisme lainnya yang dapat dipergunakan untuk mengendalikan hama dan penyakit tanaman tanpa memberikan fitotoksin terhadap tanaman serta tidak menimbulkan dampak negatif terhadap lingkungan (Sopialena, 2018).

Dewasa ini telah berhasil dikembangkan beberapa produk agens hayati yang diharapkan dapat menggantikan ketergantungan penggunaan pestisida sintesis. Ada agens hayati yang bersifat tunggal, misalnya hanya bakteri antagonis saja atau jamur antagonis saja. Ada juga agens hayati yang merupakan perpaduan dari bakteri antagonis dan jamur antagonis dalam satu kemasan. Agen hayati Tribac yang efektifitasnya diuji dalam penelitian ini, merupakan salah satu produk perpaduan dari bakteri antagonis Coryne bacterium maupun bakteri Pseudomonas fluorecens dengan jamur antagonis Trichoderma sp.

Berdasarkan uraian diatas, dilakukan penelitian untuk mengetahui efektifitas agen hayati Tribac mengendalikan patogen penyakit hawar daun Helminthosporium sp. yang menyerang tanaman jagung. Hipotesa yang diajukan, diduga agens hayati Tribac efektif mengendalikan patogen hawar daun Helminthosporium sp. pada tanaman jagung dan diperkirakan ada tingkat konsentrasi yang efektif menekan perkembangan penyakit hawar daun tersebut. 


\section{METODE PENELITIAN}

Penelitian dilaksanakan pada bulan Maret - Juni tahun 2018, di rumah kasa (screen house) Laboratorium Peramalan Hama Penyakit Tanaman Pangan Pematang Kerasaan Kabupaten Simalungun. Bahan yang dipergunakan antara lain: bibit jagung Pioneer, tanah top soil, pupuk urea , pupuk $\mathrm{ZA}$, pupuk $\mathrm{KCl}$, larutan clorox, aquadest dan agens hayati Tribac. Sedangkan alat-alat yang diperlukan antara lain: ember plastik berdiameter $25 \mathrm{~cm}$, triplek, cat untuk plang perlakuan, cangkul, sekop, hand spayer, mikroskop, petridish, pisau cutter, gunting, timbangan, formulir data pengamatan dan alat-alat tulis.

Pelaksanaan penelitian menggunakan rancangan acak lengkap. Faktor yang diteliti ialah pemanfaatan agens hayati Tribac untuk mengendalikan penyakit hawar daun tanaman jagung, dengan menguji 4 tingkat konsentrasi berturut-turut $0,1 \%, 0,2 \%, 0,3 \%$ dan $0,4 \%$ dan 1 perlakuan pembanding tanpa pemberian agens hayati Tribac. Masingmasing perlakuan diulang 6 kali. Untuk menjaga sterilisasi dari kemungkinan hal-hal yang mengganggu kemurnian penelitian, rumah kasa dibersihkan dari kotoran-kotoran.

Kemudian menyiapkan 30 buah polybag berukuran isi $5 \mathrm{~kg}$ untuk di isi tanah top soil sebagai media tumbuh tanaman jagung. Polibag yang telah berisi tanah top soil, disusun di dalam rumah kasa berdasarkan urutan perlakuan rancangan acak lengkap. Jarak antar polibag ditetapkan 50 $\mathrm{cm}$. Setelah media tanam dipersiapkan dan disusun di rumah kasa, setiap polibag disiram dengan air hingga lembab. Lalu dilakukan penanaman benih jagung hibrida varietas Pioner 12. Benih jagung ditanam sebanyak 1 tanaman per polibag. Seluruh perlakuan diberi kode sesuai dengan tingkat konsentrasi yang diuji. Perawatan tanaman, khususnya pemupukan dilakukan berdasarkan anjuran teknis budidaya jagung, yaitu Urea 5 gr/polibag, SP-36 4 gr/polibag, dan $\mathrm{KCl} 3$ gr/polibag. Penyiangan gulma yang tumbuh di permukaan polibag dilakukan secara manual dengan jalan mencabut, sehingga tanaman indikator jagung selama penelitian bebas dari kompetisi gulma.

\section{Pembuatan Sumber Inokulum dan Penginfeksian ke Tanaman Jagung}

Sumber inokulum hawar daun Helminthosporium turticum diambil dari daun tanaman jagung yang terinfeksi berat. Daun tanaman yang terinfeksi dibersihkan dari kotoran dan kemudian dicuci dengan aquadest, lalu di potong - potong dengan ukuran $1 \mathrm{~cm} \times 1 \mathrm{~cm}$. Potongan-potongan tersebut di masukkan ke dalam cawan petridish yang berisi media potato dextro agar (PDA). Potongan daun yang terinfeksi di letakkan pada PDA sebanyak 3 unit dengan posisi letak segi tiga dengan jarak $2 \mathrm{~cm}$, lalu disimpan ke dalam kotak sterilisasi dan dibiarkan hingga membentuk konidia.

Jamur yang sudah tumbuh pada PDA di ambil sebanyak 5 gram untuk selanjutnya diencerkan dan diinfeksikan dengan jalan menyemprotkannya kepada setiap tanaman yang diuji. Pelaksanaan penginfeksian inokulum kepada tanaman jagung dilakukan pada saat tanaman jagung berumur 10 HST. Setelah sumber inokulum diinfeksikan, dilakukan pengamatan untuk memastikan tanaman indikator benar-benar telah terinfeksi penyakit hawar daun. Gejala tanaman yang dinyatakan terinfeksi hawar daun (Hamidson, dkk., 2019), antara lain muncul bercak kecil berbentuk bulat memanjang pada daun, kemudian bercak berkembang membesar berbentuk oval. Gejala bercak yang semakin melebar dapat bersatu dengan bercak yang lain, sehingga menyebabkan jaringan daun mati dan mengering (nekrosis).

\section{Pembuatan Agens Hayati Tribac}

Agen hayati Tribac dibuat dengan prosedur sebagai berikut. Bahan bakteri antagonis Coryne bacterium dan jamur antagonis Tricoderma spp dimasukkan ke dalam baskom plastik dengan perbandingan 
10 : 1 (10 liter bakteri antagonis Coryne bacterium dan $1 \mathrm{~kg}$ jamur antagonis Tricoderma sp.). Di dalam baskom keduanya diaduk, hingga jamur Tricoderma sp. keluar atau lepas dari media tumbuhnya. Selanjutnya disaring dan larutan hasil penyaringan dimasukkan ke dalam wadah jerigen putih dan siap untuk diaplikasikan.

Sebelum diaplikasikan, agen hayati Tribac dianjurkan disimpan di cool box di tempat sejuk. Aplikasi agens hayati Tribac dilakukan 6 kali selama penelitian, yaitu pada saat tanaman jagung berumur 28, 35, 42, 49, 56, dan 63 HST. Aplikasi Tribac dilakukan dengan cara menyemprotkan larutan Tribac ke bagian daun tanaman jagung sesuai tingkat konsentrasi yang diuji.

Untuk mengetahui efektivitas agens hayati Tribac mengendalikan penyakit hawar daun Helminthosporium sp. yang telah diinfeksikan kepada tanaman jagung, dilakukan pengamatan intensitas serangan penyakit. Pengamatan dilakukan sebanyak 6 kali pada masing-masing tanaman yang telah disemprot agen hayati Tribac. Pengamatan intensitas serangan, dilakukan pada saat tanaman berumur 28, 35, 42, 49, 56, dan 63 HST.

\section{Pengamatan Intensitas Serangan Penyakit}

Pengamatan dilakukan dengan menghitung intensitas kerusakan daun tanaman yang disebabkan oleh hawar daun Helminthosporium turticum.

Tingkat intensitas kerusakan daun tanaman jagung dihitung menggunakan rumus Direktorat Perlindungan Tanaman Pangan (2007) $: I=\left\{\sum\right.$ (ni x vi) / $\left.(Z \times x)\right\} x$ $100 \%$, dimana : $\mathrm{I}=$ intensitas serangan $(\%)$, ni=jumlah tanaman atau bagian tanaman contoh dengan skala kerusakan vi, vi = nilai skala kerusakan contoh ke - i, N=jumlah tanaman atau bagian tanaman contoh yang diamati, dan $\mathrm{Z}=$ nilai skala kerusakan tertinggi. Nilai skala yang dipergunakan adalah : skala $0=$ tidak ada kerusakan pada daun, skala $1=$ bercak berupa titik jarum atau beberapa mm tetapi belum berbentuk elips, skala 3=bercak berbentuk elips ukuran $2 \mathrm{~mm}$ - $20 \mathrm{~mm}$ luas permukaan daun yang terinfeksi mencapai $2 \%$, skala $5=$ luas permukaan daun terinfeksi $2 \%-10 \%$, skala 7 =luas permukaan daun terinfeksi $10 \%$ $50 \%$, dan skala $9=$ luas permukaan daun terinfeksi $50 \%-100 \%$.

\section{HASIL DAN PEMBAHASAN}

Nilai Skala Kerusakan Tanaman Jagung Akibat Helminthosporium sp. Setelah Aplikasi Agens Hayati Tribac

Data pengamatan nilai skala kerusakan tanaman jagung akibat serangan hawar daun setelah aplikasi I, II, III, IV, V dan VI agens hayati Tribac pada saat tanaman jagung berumur 28, 35, 42, 49, 56, dan 63 HST dijadikan dasar untuk mengetahui intensitas serangan patogen. Dari data nilai skala kerusakan, melalui perhitungan rumus: $\mathrm{I}=\left\{\sum\right.$ (ni $\mathrm{x}$ vi) $/(\mathrm{Z} \mathrm{x}$ N) $\} \times 100 \%$, diperoleh data intensitas kerusakan tanaman jagung, seperti tertera pada tabel 1 .

Dari hasil analisis sidik ragam diketahui, aplikasi agens hayati Tribac dalam berbagai tingkat konsentrasi mempengaruhi intensitas kerusakan tanaman jagung. Untuk mengetahui perbedaan intensitas kerusakan tanaman jagung antar tingkat konsentrasi, dilakukan pengujian dengan uji jarak Duncan yang hasilnya dapat dilihat pada tabel berikut. 
Tabel 1. Intensitas Serangan Penyakit Hawar Daun Tanaman Jagung Setelah Aplikasi Agens Hayati Tribac

\begin{tabular}{ccccccc}
\hline Perlakuan & \multicolumn{5}{c}{ Intensitas Serangan Hawar Daun (\%) Setelah Aplikasi Agen Hayati Tribac } \\
\cline { 2 - 6 } & I $(28 \mathrm{HST})$ & II $(35 \mathrm{HST})$ & III $(42 \mathrm{HST})$ & IV $(49 \mathrm{HST})$ & $\mathrm{V}(56 \mathrm{HST})$ & VI (63 HST) \\
\hline $\mathrm{T}_{0}$ & $14,88 \mathrm{a}$ & $16,50 \mathrm{a}$ & $18,00 \mathrm{a}$ & $32,10 \mathrm{a}$ & $35,63 \mathrm{a}$ & $60,00 \mathrm{a}$ \\
$\mathrm{T}_{1}$ & $11,88 \mathrm{~b}$ & $13,40 \mathrm{~b}$ & $14,00 \mathrm{~b}$ & $26,00 \mathrm{~b}$ & $28,63 \mathrm{~b}$ & $48,70 \mathrm{~b}$ \\
$\mathrm{~T}_{2}$ & $8,75 \mathrm{c}$ & $9,70 \mathrm{c}$ & $9,90 \mathrm{c}$ & $20,50 \mathrm{c}$ & $21,60 \mathrm{c}$ & $36,00 \mathrm{c}$ \\
$\mathrm{T}_{3}$ & $5,40 \mathrm{~d}$ & $6,30 \mathrm{~d}$ & $6,50 \mathrm{~d}$ & $14,40 \mathrm{~d}$ & $15,33 \mathrm{~d}$ & $24,30 \mathrm{~d}$ \\
$\mathrm{~T}_{4}$ & $1,85 \mathrm{e}$ & $3,00 \mathrm{e}$ & $3,00 \mathrm{e}$ & $7,50 \mathrm{e}$ & $8,50 \mathrm{e}$ & $11,00 \mathrm{e}$ \\
\hline
\end{tabular}

Keterangan : Angka yang diikuti oleh notasi huruf yang sama pada kolom yang sama, menyatakan tidak berbeda nyata berdasarkan uji jarak Duncan pada selang kepercayaan $95 \%$.

Pada pengamatan pertama (28 HST), serangan penyakit hawar daun Helminthosporium sp. masih sedikit. Pada pengamatan ini, intensitas serangan terbesar terdapat pada perlakuan tanpa aplikasi agen hayati Tribac $\mathrm{T}_{0} \quad(14,88 \%)$. Sedangkan intensitas serangan terendah $(1,85 \%)$ dihasilkan tingkat konsentrasi aplikasi $0,4 \%$ $\left(\mathrm{T}_{4}\right)$.

Hal ini disebabkan pada aplikasi pertama intensitas serangan hawar daun Helminthosporium sp. masih baru muncul. Pelaksanaan penginfeksian inokulum kepada tanaman jagung dilakukan pada saat tanaman jagung berumur 10 HST. Gejala pertama penyakit hawar daun mula-mula terlihat bercak kecil, kemudian bercak semakin memanjang berbentuk elips. Bercak-bercak tersebut pertama kali terdapat pada daun bawah (daun tua) kemudian berkembang menuju daun atas (daun muda).

Pada pengamatan kedua (35 HST), terlihat intensitas serangan semakin meningkat dibanding pengamatan pertama pada saat 28 HST. Pada 35 HST, intensitas serangan tertinggi juga dihasilkan $\mathrm{T}_{0}$ $(16,50 \%)$ dan intensitas serangan terendah $(3,00 \%)$ terdapat pada tingkat konsentrasi $0,4 \% \quad\left(\mathrm{~T}_{4}\right)$. Pada pengamatan 35 HST diketahui bahwa seluruh perlakuan menghasilkan intensitas serangan yang berbeda nyata. Pada pengamatan ketiga (42 HST) secara visuil terlihat bagian bawah tanaman jagung sudah ada yang mengering, namun bagian atas belum terdapat serangan hawar daun Helminthosporium sp. Hasil ini sejalan dengan pendapat Sudjono (2018) yang menyatakan penyakit hawar daun, awalnya menyerang daun bagian bawah dan akan menyebar ke daun yang lebih muda. Pada pengamatan ketiga (42 HST), nilai intensitas serangan penyakit cenderung mengikuti pola intensitas hasil pengamatan sebelumnya. Intensitas serangan tertinggi $(18,00 \%)$ tetap dihasilkan perlakuan tanpa aplikasi agen hayati Tribac. Sedangkan serangan terendah $(3,00 \%)$ dihasilkan perlakuan $\mathrm{T}_{4}$ (tingkat konsentrasi aplikasi $0,4 \%)$.

Pengamatan keempat (49 HST), intensitas serangan hawar daun tertinggi sudah mencapai $32,10 \% \quad\left(\mathrm{~T}_{0}\right)$. Pemberian Tribac dengan konsentrasi yang bertingkat, mampu menekan intensitas penyakit, namun tetap ada peningkatan intensitas serangan. Pada pengamatan kelima (56 MST), terlihat intensitas serangan terus mengalami peningkatan. Intensitas serangan tertinggi $(35,63 \%)$ tetap dihasilkan perlakuan tanpa agen hayati Tribac $\left(\mathrm{T}_{0}\right)$, disusul perlakuan Tribac konsentrasi rendah. Dari tabel terlihat, semakin tinggi tingkat konsentrasi aplikasi Tribac, intensitas serangan cenderung semakin menurun. Tingkat konsentrasi aplikasi Tribac 0,4\% menghasilkan intensitas serangan patogen hawar daun yang terendah (hanya $8,50 \%$ ) yang berbeda nyata dengan perlakuan lainnya. 
Hasil pengamatan terakhir (63 HST), memperlihatkan pola yang sejalan dengan hasil pengamatan sebelum-sebelumnya. Intensitas serangan yang dihasilkan perlakuan tanpa penyemprotan agen hayati Tribac $\left(\mathrm{T}_{0}\right)$ menghasilkan intensitas serangan hawar daun yang tertinggi, mencapai $60,00 \%$. Tingkat konsentrasi aplikasi Tribac yang menghasilkan intensitas serangan yang terendah $(11,00 \%)$ dihasilkan oleh tingkat konsentrasi aplikasi Tribac 0,4\% yang berbeda nyata dengan perlakuan lainnya. Perlakuan tingkat konsentrasi aplikasi Tribac $0,4 \%$ untuk seluruh tahapan pengamatan memperlihatkan intensitas serangan yang terkecil.

Grafik intensitas serangan penyakit hawar daun setelah 6 kali aplikasi agen hayati Tribac tertera paga gambar 1. Dari gambar terlihat semakin tua umur tanaman jagung, intensitas serangan penyakit hawar daun cenderung semakin menaik. Laju peningkatan intensitas serangan yang paling rendah pada setiap stadia umur tanaman, dihasilkan oleh aplikasi agen hayati Tribac dengan tingkat konsentrasi tertinggi $(0,4 \%)$.

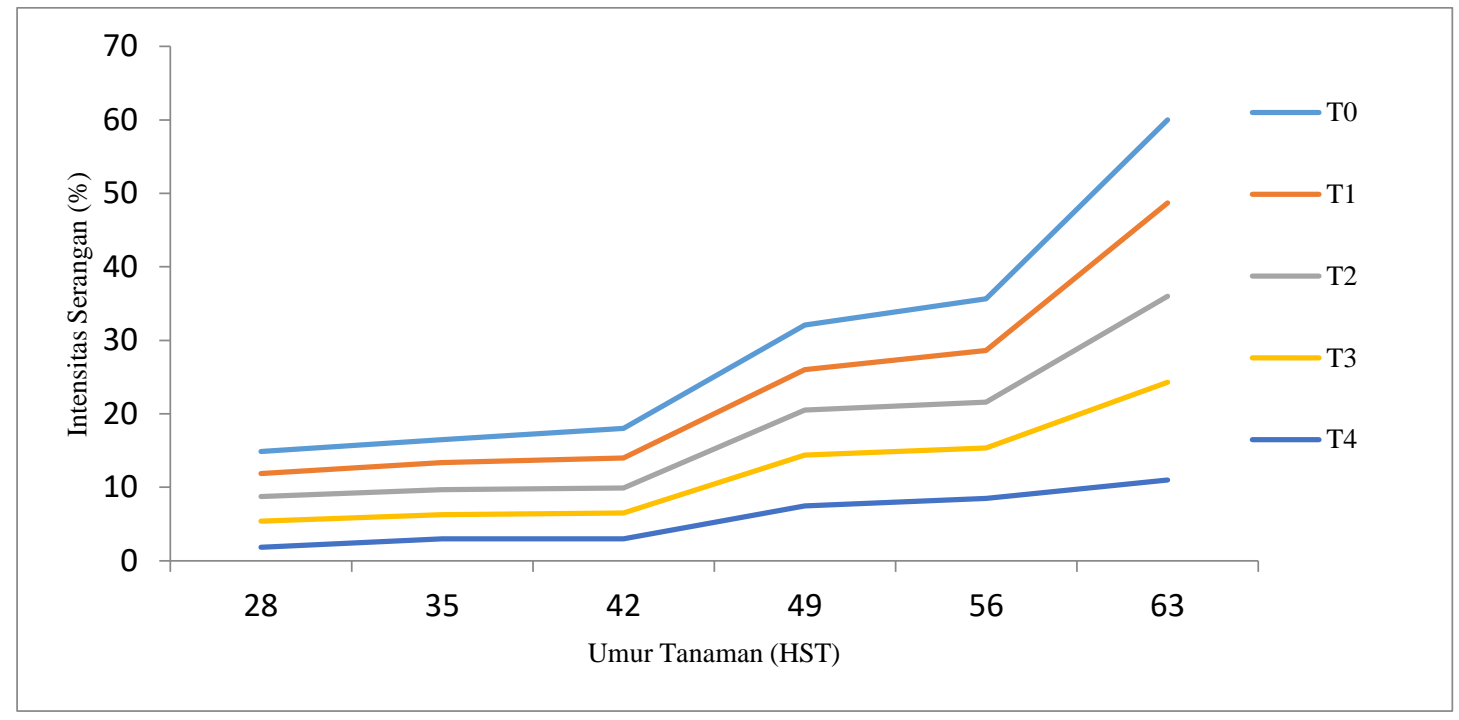

Gambar 1. Grafik Intensitas Serangan Hawar Daun Helminthosporium sp. setelah Aplikasi Agen Hayati Tribac

Hasil ini sejalan dengan laporan Dharma (1993) dalam Prematirosari (2006) yang menyatakan intensitas serangan patogen cenderung meningkat dengan bertambahnya umur tanaman. Pada saat tanaman jagung berumur 66 hari, Dharma (1993) melaporkan intensitas serangan penyakit hawar daun mencapai 78,72\%. Gambar 1 memperlihatkan laju peningkatan intensitas serangan yang paling rendah pada setiap stadia umur tanaman, dihasilkan oleh aplikasi agen hayati Tribac dengan tingkat konsentrasi tertinggi $\mathrm{T}_{4}(0,4 \%)$. Analisis regresi tingkat kesembuhan tanaman jagung dari serangan penyakit hawar daun setelah aplikasi agen hayati Tribac memperlihatkan hubungan yang bersifat linier (gambar 2). Terlihat kecenderungan, semakin tinggi tingkat konsentrasi agen hayati Tribac, tingkat kesembuhan tanaman semakin besar (intensitas serangan semakin kecil). Perlakuan kontrol (tanpa agens hayati Tribac) menghasilkan intensitas serangan penyakit hawar daun paling besar. Hasil ini mengindikasikan agen hayati Tribac bisa dimanfaatkan untuk mengurangi (memperkecil) perkembangan penyakit hawar daun yang disebabkan pathogen Helminthosporium $s p$. 


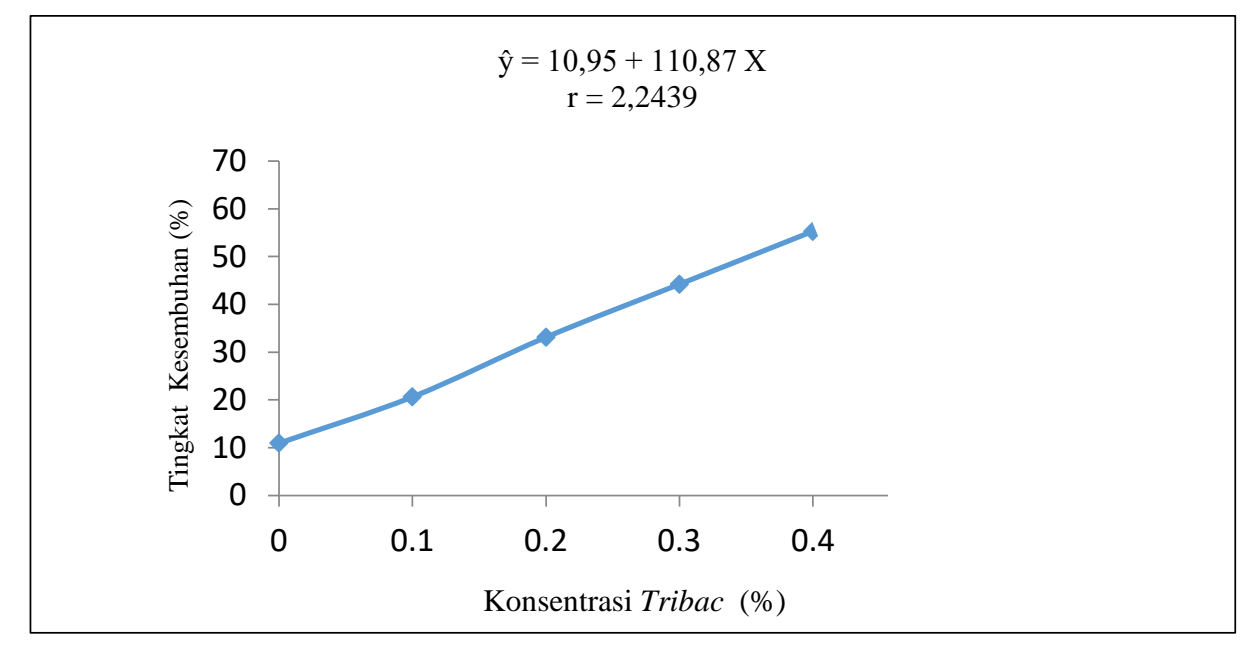

Gambar 2. Kurva Respons Tingkat Kesembuhan Tanaman Jagung dari Penyakit Hawar Daun Helminthosporium sp. Akibat Aplikasi Agen Hayati Tribac

Sihombing (2010), melaporkan hasil uji lapangan pengendalian Helminthosporium sp yang menyerang tanaman jagung. Dengan mengaplikasikan Trichoderma sp. secara tunggal hanya dapat mengendalikan penyakit kurang lebih $45 \%$. Dengan Coryne bakterium secara tunggal, juga hanya dapat menekan tingkat kerusakan yang disebabkan jamur Helminthosporium sp. sebesar $47.5 \%$. Dengan penggabungan bakteri antagonis Coryne bacterium dan jamur antagonis Trichoderma sp. dapat menekan perkembangan jamur Helminthosporium sp hingga 95\%. Hal ini sejalan dengan hasil uji aplikasi agens hayati Tribac yang dilakukan. Pada pengamatan terakhir (56 HST) tingkat konsentrasi aplikasi Tribac 0,4\% menghasilkan intensitas serangan yang terendah $(11,00 \%)$. Ini berarti agens hayati Tribac yang diuji mampu menekan tingkat kerusakan tanaman jagung yang disebabkan jamur Helminthosporium sp sebesar $89 \%$.

Selain Jamur antagonis, Trichoderma sp. juga mampu memproduksi senyawa ekstraseluler eksokitinase yang menghasilkan fungitoksic yang bekerja mendegradasi dinding sel patogen. Selain itu, hifa Trichoderma juga memproduksi enzim yang mampu mendegradasi dinding sel patogen penyebab penyakit. Hifa yang telah berhasil mendegradasi dinding sel patogen, selanjutnya akan masuk ke dalam lumen jamur target. Maspary (2011) menyatakan, Jamur antagonis Trichoderma sp. merupakan agens pengendali hayati yang mempunyai banyak mekanisme dalam menyerang dan merusak patogen tanaman. Jamur Trichoderma sp. diketahui memiliki beberapa mekanisme dalam pengendalian penyakit tanaman seperti melalui mikoparasit, induksi resistensi, serta pemacu pertumbuhan. Coryne bacterium merupakan salah satu agen hayati. Selain bakteri antagonis, Coryne bacterium juga dapat mengendalikan penyakit hawar daun yang disebabkan oleh jamur Exserohilum turticum, bercak daun Helminthosporium $\mathrm{sp}$ dan Cercospora $\mathrm{sp}$ pada tanaman jagung, penyakit akar gada (Plasmodiophora brassicae) pada tanaman kubis, penyakit layu bakteri (Ralstonia solanacearum) pada tanaman pisang, serta hawar daun jingga yang disebabkan Pseudomonas sp pada tanaman padi (Maspary, 2011).

Dari uji aplikasi agens hayati Tribac yang dilakukan, ada persesuaian dengan hasil uji yang dilaksanakan Sinaga (2008) yang menyimpulkan, bahwa jamur Trichoderma sp 
merupakan jamur yang dapat menjadi agen biokontrol. Jamur ini bersifat antagonis bagi jamur lainnya, dimana aktifitas antagonis yang dimaksud dapat meliputi persaingan, parasitisme dan predasi dalam pengendalian organism pengganggu tanaman dan bersifat ramah lingkungan.

Penerapan pengendalian hama terpadu (PHT) untuk mengendalikan OPT merupakan kesadaran baru dalam di bidang pertanian. Yaitu dengan cara memaksimalkan penerapan berbagai metode pengendalian hama secara kompherensif dan mengurangi pemakaian pestisida. Salah satu komponen PHT tersebut adalah pengendalian hayati dengan memanfaatkan bakteri antagonis. Berbagai penelitian tentang bakteri antagonis, terbukti bahwa beberapa jenis bakteri, potensial digunakan sebagai agensia hayati. Bakteri-bakteri antagonis ini selain dapat menghasilkan antibiotik, juga bisa berperan sebagai kompetitor terhadap unsur hara bagi patogen tanaman.

Agen hayati Tribac merupakan perpaduan antara jamur dan bakteri yang dapat mengendalikan penyakit hawar daun Helminthosporium sp. Dalam hal ini jamur Trichoderma sp. berperan sebagai agens biokontrol karena bersifat antagonis terhadap jamur lainnya. Sedangkan bakteri Coryne bacterium juga berperan sebagai bakteri antagonis yang dapat mengendalikan hawar daun Helminthosporium sp. Sifat antagonis Trichoderma sp. disebabkan Trichoderma sp. mampu menghasilkan metabolit gliotoksin dan viridin sebagai antibiotik dan beberapa spesies juga menghasilkan sejumlah enzim ekstraseluler beta $(1,3)$ glukonase dan kitinase yang dapat melarutkan dinding sel patogen dan menyebabkan eksolisis pada hifa inangnya. Beberapa anggota Trichoderma sp. juga ada yang menghasilkan toksin trichodermin. Toksin tersebut dapat menyerang dan menghancurkan propagul yang berisi spora-spora patogen disekitarnya. Tetapi proses yang terpenting adalah kemampuan mikoparasit dan persaingannya yang kuat dengan patogen (Maspary, 2011).

\section{KESIMPULAN}

Aplikasi agens hayati Tribac efektif mengendalikan penyakit hawar daun yang disebabkan patogen Helminthosporium sp. pada tanaman jagung. Tingkat konsentrasi aplikasi agen hayati Tribac 0,4\% menghasilkan penurunan intensitas serangan yang terendah (11\%). Agen hayati Tribac berperan membatasi perkembangan penyakit hawar daun, tetapi belum memperlihatkan hasil menyembuhkan atau menghilangkan penyakit secara total.

\section{SARAN}

Perlu dilakukan penelitian lanjutan, dengan menguji tingkat konsentrasi agen hayati Tribac yang lebih tinggi, sehingga didapatkan tingkat konsentrasi yang efektif untuk pengendalian penyakit hawar daun tanaman jagung.

\section{UCAPAN TERIMA KASIH}

Penghargaan dan ucapan terima kasih yang setinggi-tingginya disampaikan kepada Kepala Laboratorium Peramalan Hama Penyakit Tanaman Pangan Pematang Kerasaan Kabupaten Simalungun atas izin penggunaan fasilitas laboratorium dan juga kepada Staf Laboratorium yang telah membantu penulis mulai dari persiapan hingga pelaksanaan penelitian.

\section{DAFTAR PUSTAKA}

Adisarwanto, T dan Y.E. Widyastuti. 2000. Meningkatkan Produksi Jagung. Penebar Swadaya, Jakarta.

Dharma A. 1993. Pengamatan Penyakit Penting Pada Tanaman Kacang Tanah (Arachis hypogaea L.), Jagung Manis (Zea mays saccharata Sturt.) dan Kedelai (Glycine max L.) di Kebun Percobaan IPB Cikarawang, Kabupaten Bogor. Fakultas Pertanian, Institut Pertanian Bogor. 
Direktorat Perlindungan Tanaman Pangan, 2007. Pedoman Pengantar dan Pelaporan Perlindungan Tanaman Pangan dan Hortikultura. Direktorat Perlindungan Tanaman Pangan. Jakarta.

Girsang, W. 2009. Dampak Negatif Penggunaan Pestisida. Fakultas Pertanian. Universitas Simalungun Pematangsiantar.

Hamidson H, Suwandi S, Effendy TA. 2019. Development of some corn leaf diseases caused by mushrooms in north Indralaya Sub-District Ogan Ilir District. In: Herlinda $\mathrm{S}$ et al. (Eds.), Prosiding Seminar Nasional Lahan Suboptimal 2019, Palembang 4-5 September 2019. Palembang: Unsri Press.

Maspary, 2011. Trichoderma sp Sebagai Pupuk Biologis dan Biofungisida. http://www.gerbangpertanian.com/20 11/02/trichoderma-sp-sebagai-pupukbiologis.html

Prematirosari, M.B. 2006. Pengendalian Penyakit Hawar Daun (Helminthosporium turcicum) pada Jagung Manis Dengan Bakteri Pemacu Pertumbuhan Tanaman. https://repository.ipb.ac.id/jspui/handl e/123456789/1657.diakses 20 Agustus 2018.

Roliyah, Y., 2000. Laporan Perkembangan Penyakit Hawar Daun Pada Tanaman Jagung di Provinsi Sumatera Utara. Balai Proteksi Tanaman Pangan dan Hortikultura I, Medan.

Saenong, MS. 2007. Beberapa Senyawa Pestisida yang Berbahaya. Prosiding Seminar Ilmiah dan Pertemuan Tahunan PEI dan PFI XVIII Komda Sulawesi Selatan. http://www.peiffikomdasulsel.org

Sihombing., 2010. Analisis Perbanyakan Agens Hayati. Laboratorium PHP Pematang Kerasaan.
Sinaga, MS., 2008. Tehnologi Pengendalian Agens Hayati, Institut Pertanian Bogor

Sopialena, 2018. Pengendalian Hayati dengan Memberdayakan Potensi Mikroba. Mulawarman University Press. Samarinda.

Sudjono, M.S. 2018. Penyakit Jagung dan Pengendaliannya.

http://balitsereal.litbang.pertanian.go. $\mathrm{id} / \mathrm{wp}$ content/uploads/2018/08/11penyakit.pd $\mathrm{f}$ 
